\title{
Assessment of Indoor and Outdoor Background Radiation Levels at School of Technology, Kano State Polytechnic, Kano State-Nigeria
}

\author{
1*BARAYA, JT; ${ }^{2}$ SANI, MH; ${ }^{1}$ ALHASSAN, M \\ ${ }^{* 1}$ Department of Physics, Federal University Dutsin-Ma, Katsina State, Nigeria \\ ${ }^{2}$ Department of Science Laboratory Technology, School of Technology, Kano State Polytechnic, Kano Sate, Nigeria \\ *Corresponding Author Email: tjamilu@ fudutsinma.edu.ng, Tel.:+234 - 8036959101
}

\begin{abstract}
A Survey taken by the world health organization (WHO) and the international commission on radiation protection (ICRP) shows that residents of temperate climate spends only about $20 \%$ of their time outdoor and about $80 \%$ indoors and certain materials use for the construction of such buildings (rocks, soils, tiles etc) are known to be radioactive, and exposure to such radiation results in critical health challenges. Assessment of indoor and outdoor background ionizing radiation level at School of Technology, Kano State Polytechnic, Nigeria was carried out using a digital radiation meter (Radiation Alert Inspector). A total of 49 areas were surveyed and the results obtained showed that the annual indoor reading were highest at Compounding Lab. $(2.368 \pm 0.35 \mathrm{mSv} / \mathrm{yr})$ and Old Chemistry Lab. $(2.169 \pm 0.35 \mathrm{mSv} / \mathrm{yr})$, and lowest at New Biology Lab. $(1.219 \pm 0.21 \mathrm{mSv} / \mathrm{yr})$ and Press Workshop $(1.303 \pm 0.35 \mathrm{mSv} / \mathrm{yr})$. For the outdoor areas, SOT ring road was found to have the highest value of $0.557 \pm 0.17 \mathrm{mSv} / \mathrm{yr}$, while Zoological Garden has the lowest effective value of $0.280 \pm 0.05 \mathrm{mSv} / \mathrm{yr}$. For the lecture venues, Auditorium has the highest indoor annual equivalent dose of $2.060 \pm 0.49 \mathrm{mSv} / \mathrm{yr}$, while H-Block ND I Textile Class recorded the lowest values of $1.275 \pm 0.27 \mathrm{mSv} / \mathrm{yr}$. Base on the aforementioned findings, it was deduced that radiation levels are within the permissible radiation limit as stipulated by the ICRP and UNSCEAR of $2.4 \mathrm{mSv} / \mathrm{yr}$ and thus, SOT Kano is radiologically safe.
\end{abstract}

\section{DOI: https://dx.doi.org/10.4314/jasem.v23i3.30}

Copyright: Copyright (C) 2019 Baraya et al. This is an open access article distributed under the Creative Commons Attribution License (CCL), which permits unrestricted use, distribution, and reproduction in any medium, provided the original work is properly cited.

Dates: Received: 17 November 2018; Revised: 19 January 2019; Accepted 22 January 2019

Keywords: Indoor and outdoor, background radiation, equivalent dose, Digital Radiation meter.

Radiation has been found to be beneficial on one hand and harmful on the other hand and is encountered in everyday activities in various forms and different intensities. Some of the harmful effects are: cancer, cataract, gene mutation destruction of bones and blood cells and it can cause the death of an individual (Ogola et al., 2016). Materials used for building (soil and rock) are major sources of radiation exposure to the population and also a means of migration for the transfer of radionuclide into the environment. Radon gas from the earth crust is the most abundant source of natural radiation in the environment. The radioactive disintegration of uranium-238 produces ${ }^{222} \mathrm{Rn}$ which in turn decays with a half-life of 3.82 days (Masok et al., 2015). As it is inhaled, it penetrates into the lungs and the continuous deposition and penetration of such high energy particles through the lungs leads to tissue damage and mutation which leads to incidence of lung cancer (Chad-Umoren et al., 2007). The International Commission on Radiation Protection (ICRP) in 1990 set a worldwide annual equivalent dose rate limit of exposure to ionizing radiation to $1 \mathrm{mSv} / \mathrm{yr}$ for the protection of human beings and wildlife (ICRP, 1990) while the average effective dose rate limit of $2.4 \mathrm{mSv} / \mathrm{yr}$ was set by the United Nation Scientific Committee on the Effects of Atomic Radiations (UNSCEAR) for most indoor facilities such as research laboratories, conference halls, lecture venues, offices, etc. (UNSCEAR, 2000). Previous studies have shown that areas with high background radiation are found in Yangjiang, China; Kerele, India; and Ramsar, Iran (Ghiassi-nejad et al., 2002); as well as in Asia, maximum outdoor measurement was recorded in Malaysia and the maximum indoor measurement was recorded in Hong Kong and Iran (Gholami et al., 2011).In Nigeria, outdoor background ionizing radiation profile has received much attention than indoor background ionizing radiation, even though studies have established the presence of dangerous background ionizing radiation within buildings. Indoor background ionizing radiation investigation is also important, because due to changes in lifestyle people spend more time indoors than outdoors. Surveys taken by the World Health Organization (WHO) and the International Commission on Radiological Protection (ICRP) show that residents of temperate climates spend only about $20 \%$ of their time outdoors and $80 \%$ indoors (their homes, offices, schools and other buildings) (Chad-Umoren et al., 2007). The implication of this statistics is obvious; the probability of exposure to dangerous radiation is higher indoors than outdoors. Studies have been conducted in different parts of Nigeria to measure the natural radiation level in the areas. For instance, Farai IP and Vincent UE (2016), reported that the equivalent dose due to outdoor exposure to radiation in Abeokuta, Nigeria ranged from 0.19 to $1.64 \mathrm{mSv} / \mathrm{yr}$ with the mean of $0.45 \mathrm{mSv} / \mathrm{yr}$. Sadiq AA and Agba EH (2012)

*Corresponding Author Email: tjamilu@fudutsinma.edu.ng, Tel.:+234 - 8036959101 
investigates the indoor and outdoor radiation level in keffi Nigeria and reported that Some areas were found to have a relatively higher indoor dose, while others had a higher outdoor dose equivalent rate, but they are in good approximation with the internationally approved annual dose limits for members of the public (1mSv/yr). Tikya EV et al (2017) assessed the ambient radiation level at the take-off campus of Federal University Dutsin-Ma, Katsina state, Nigeria using a digital radiation meter, the results obtained showed that, the Old Biology laboratory and Biochemistry laboratory were found to have the highest values of indoor annual equivalent dose, and concluded that the ambient indoor and outdoor radiation levels at the take-off site of FUDMA are within the safety limits. James IU et al. (2015) carried out measurement of indoor and outdoor ionizing radiation level at Kwali General Hospital, Abuja Nigeria using a well calibrated Geiger Muller counter, their study revealed that the average annual equivalent dose rate is $0.750 \pm$ $0.020 \mathrm{mSv} / \mathrm{yr}$ and $0.189 \pm 0.005 \mathrm{mSv} / \mathrm{yr}$ for indoor and outdoor measurements respectively. These results were below the $1 \mathrm{mSv} / \mathrm{yr}$ maximum permissible limit for the public set by International Commission on Radiological Protection (ICRP). Therefore, Kwali General Hospital is radiologically safe. Felix BM et al. (2015), assess the background ionizing radiations at Biochemistry, Chemistry, Microbiology and physics laboratories of Plateau State University Bokkos using Gamma-scout Radiometer. The purpose of the study was to adjust the meter to detect the alpha, beta and gamma types of radiation in $\mu \mathrm{Sv} / \mathrm{hr}$. The mean equivalent dose rate per hour for indoor background radiation for the laboratories was found to be 0.256 $\mu \mathrm{Sv} / \mathrm{hr}$ while the outdoor was $0.249 \mu \mathrm{Sv} / \mathrm{hr}$. The mean annual equivalent dose rate of the laboratories was computed for indoor and outdoor background radiation level to be $1.54 \mathrm{mSv} / \mathrm{yr}$ and $0.44 \mathrm{mSv} / \mathrm{yr}$ respectively, and are in a good proportion below the world wide average dose of $2.4 \mathrm{mSv} / \mathrm{yr}$.

The objectives of the present work are to measure the background ionizing radiation, assess the level of Annual Indoor and Outdoor Effective Dose Rates of School of Technology, Kano State Polytechnic, and compare the findings with the documented guidelines on radiation protection and safety.

\section{MATERIALS AND METHODS}

The indoor and outdoor background radiations of School of Technology, Kano were surveyed using Digital Radiation Meter (Radiation Inspector Alert) and Geographical Positioning System (GPS) to determine the geographical locations of the areas.

The radiation meter was held one meter above the ground to capture the average exposure level (height) of the human body and oriented vertically upward during the measurement of readings so as to expose the window of the device to incoming radiation.
The effective dose readings were taken in milliRöentgen per hour $(\mathrm{mR} / \mathrm{hr})$ directly from the display screen of the radiation meter. The results were then converted to micro-Sievert per hour $(\mu \mathrm{Sv} / \mathrm{hr})$ and then finally converted to micro-Sievert per year ( $\mu \mathrm{Sv} / \mathrm{yr})$.

Forty-nine sample areas (A1..., A49) were selected within the study area. Outdoor background radiation readings were taken in open fields that are away from buildings and Indoor measurements were conducted inside the buildings. To account for errors in the data, ten readings were taken, five indoors and five outdoors in each sample area and the standard deviation of each data was obtained.

UNSCEAR (1988) recommended indoor and outdoor occupancy factors of 0.8 and 0.2 respectively. This occupancy factor is the proportion of the total time during which an individual is exposed to a radiation field. Eight thousand seven hundred and sixty hours per year $(8760 \mathrm{hr} / \mathrm{yr})$ were used. Equation (i) converts radiation in milliRöentgen per hour to micro - Sievert per hour, equation (ii) converts the indoor equivalent dose from micro - Sievert per hour to milliSievert per year, equation (iii) converts the outdoor equivalent dose from micro - Sievert per hour to milliSievert per year, while equation (iv) is used to find the standard deviation. $\mathrm{X}$ is the reading displayed directly from the radiation meter, $\mathrm{Y}$ and $\mathrm{Z}$ are the converted indoor and outdoor meter's readings to micro-Sievert per hour while IAEDR and OAEDR are the Indoor and Outdoor Annual Effective Dose Rates for different places respectively.

$$
\begin{aligned}
& X(\mu S v / h r)=Y(m R / h r) \times 10 \\
& \operatorname{IAEDR}(\mathrm{mSv} / \mathrm{yr})=\mathrm{Y}(\mu \mathrm{Sv} / \mathrm{hr}) \times 8760(\mathrm{hr} / \mathrm{yr}) \times 0.8 \div 1000 \\
& \text { OAEDR }(\mathrm{mSv} / \mathrm{yr})=\mathrm{Z}(\mu \mathrm{Sv} / \mathrm{hr}) \times 8760(\mathrm{hr} / \mathrm{yr}) \times 0.2 \div 1000
\end{aligned}
$$

$S . D=\sqrt{\frac{\Sigma(x-\bar{x})^{2}}{N}}$

Study Area: School of Technology (also known as SOT) is one of the five units of Kano state Polytechnic. Established in 1975 with the main aim of providing trained manpower and strengthening the socioeconomic and political development of Kano state and Nigeria in general. SOT is situated at Matan Fada road in Nasarawa Local Government Area of Kano state. Nasarawa LGA lies on latitude $11^{0} 58^{\prime} \mathrm{N}$ and longitude $8^{0} 33^{\prime} \mathrm{E}$. It is among the 8 local government areas (LGAs) that made up Kano metropolis with an Area of $34 \mathrm{~km}$ square and a population of 596,669 at the 2006 census (NIPOST, 2009).

Data Analysis: The row data gotten under the method were presented in the tables, processed and analysed here using the established mathematical equations described within the context. 
RESULT AND DISCUSSION

A total of forty-nine areas were selected for this study, and none of the areas had ionizing radiation above the recommended annual standard of $2.4 \mathrm{mSv} / \mathrm{yr}$. The results are displayed in the table 1

\begin{tabular}{|c|c|c|}
\hline Area code & Location & Geographical Location \\
\hline A1 & New Biology Lab & $\mathrm{N} 11^{0} 59^{\prime} 28.4^{\prime \prime}, \mathrm{E} 008^{0} 32^{\prime} 27.2^{\prime \prime}$ \\
\hline A2 & Old Biology Lab & N $11^{0} 59$ '26.9", E008 32 '28.2" \\
\hline A3 & New Chemistry Lab & N $11^{0} 59^{\prime} 28.5^{\prime \prime}$, E008 32 '27.3" \\
\hline A4 & Old Chemistry Lab & N 11 ${ }^{0} 59$ '28.9", E00832'28.6" \\
\hline A5 & New Physics Lab & N $11^{0} 599^{\prime} 28.9^{\prime \prime}$, E00832'26.6" \\
\hline A6 & Old Physics Lab & N $11^{0} 59^{\prime} 26.6^{\prime \prime}$, E008 32 '27.8" \\
\hline A7 & Computer Science Lab I & N $11^{0} 599^{\prime} 28.8^{\prime \prime}$, E00832'22.2" \\
\hline A8 & Computer Science Lab II & N $11^{0} 5928.8^{\prime \prime}$, E00832'22.6" \\
\hline A9 & Civil Engineering Soil Lab & N 11 ${ }^{0} 59^{\prime} 30.3^{\prime \prime}$, E008 32 '22.3" \\
\hline A10 & Civil Engineering Water Lab & N 11 ${ }^{0} 59^{\prime} 30.7^{\prime \prime}$, E00832'21.6" \\
\hline A11 & Compounding Lab & N $11^{0} 59$ '26.6", E008 32 '29.4" \\
\hline A12 & Instrumentation Lab & N $11^{0} 59^{\prime} 28.8^{\prime \prime}$, E008 32 '27.9" \\
\hline A13 & Autotronics Lab & N 11059'31.7", E00832'27.9" \\
\hline A14 & Mechatronics/Autocad Lab & N $11^{0} 59^{\prime} 28.3^{\prime \prime}$, E008 32 '23.4" \\
\hline A15 & Material Science Lab & N $11^{0} 59^{\prime} 28.4^{\prime \prime}$, E008 32 '24.4" \\
\hline A16 & Control Engineering Lab & N 11059'27.3", E00832'27.3" \\
\hline A17 & Telecommunication Lab & N $11^{0} 5927.3^{\prime \prime}$, E008 32 '27.3" \\
\hline A18 & Power Plant Lab & N 11059'27.3", E00832'24.7" \\
\hline A19 & Metrology Lab & N $11^{0} 5926.7^{\prime \prime}$, E008 $32 ' 23.7^{\prime \prime}$ \\
\hline A20 & Mechanical Workshop & N $11^{0} 599^{\prime} 31.8^{\prime \prime}$, , E008 32 '23.2" \\
\hline A21 & Computer Maintenance Workshop & N 11 ${ }^{0} 59^{\prime} 30.2^{\prime \prime}, \mathrm{E} 008^{0} 32^{\prime} 28.6^{\prime \prime}$ \\
\hline $\mathbf{A 2 2}$ & Automobile Workshop & N $11^{0} 59^{\prime} 27.7^{\prime \prime}$, E008 32 '27.9" \\
\hline $\mathbf{A 2 3}$ & Press Workshop & N $11^{0} 59^{\prime} 32.3^{\prime \prime}$, E008 32 '25.3" \\
\hline A24 & Plate Making Workshop & N $11^{0} 59^{\prime} 32.3^{\prime \prime}$, E008 32 '25.5" \\
\hline $\mathbf{A 2 5}$ & Prof Hafiz Abubakar Studio Hall I & $\mathrm{N} 11^{0} 599^{\prime} 30.0^{\prime \prime}, \mathrm{E} 008^{0} 32^{\prime} 23.5^{\prime \prime}$ \\
\hline A26 & Prof Hafiz Abubakar Studio Hall II & $\mathrm{N} 11^{0} 59^{\prime} 30.5^{\prime \prime}, \mathrm{E} 008^{0} 32^{\prime} 23.6^{\prime \prime}$ \\
\hline A27 & General Drawing Studio & N $11^{0} 59^{\prime} 32.3^{\prime \prime}$, E008 32 '27.9" \\
\hline A28 & Ceramics Studio & N $11^{0} 599^{\prime} 32.6^{\prime \prime}$, E008 32 '27.9" \\
\hline A29 & NDI Fashion Class & N $11^{0} 59^{\prime} 27.5^{\prime \prime}$, E008 32 '28.7" \\
\hline A30 & NDII Textile Class & N $11^{0} 5929.8^{\prime \prime}$, E008 32 '21.9" \\
\hline A31 & Auditorium & N $11^{0} 5927.7^{\prime \prime}$, E008 32 '27.7" \\
\hline A32 & H-Block ND II Fashion Class & N 11 ${ }^{0} 599^{\prime 29.2 ", ~ E 00832 ' 25.6 " ~}$ \\
\hline A33 & H-Block ND I Textile Class & $\mathrm{N} 11^{0} 59^{\prime} 28.5^{\prime \prime}, \mathrm{E} 008^{0} 32^{\prime} 25.9^{\prime \prime}$ \\
\hline A34 & H-Block ND I C.E.T Class & N $11^{0} 59^{\prime} 27.5^{\prime \prime}$, E008 32 '25.8" \\
\hline A35 & Civil 001 Lecture Venue & $\mathrm{N} 11^{0} 59^{\prime} 30.1^{\prime \prime}, \mathrm{E} 008^{0} 32^{\prime} 22.2^{\prime \prime}$ \\
\hline A36 & Civil 002 Lecture Venue & N $11^{0} 5930.4^{\prime \prime},, \mathrm{E} 008^{0} 32^{\prime} 22.2^{\prime \prime}$ \\
\hline A37 & ND Mech. Engineering Class & N $11^{0} 5928.3^{\prime \prime}$, E008 32 '23.4" \\
\hline A38 & HND Mech. Engineering Class & N 11 ${ }^{0} 59$ '28.4", E00832'24.4" \\
\hline A39 & HND Electrical Eng. Class & N $11^{0} 5927.3^{\prime \prime}$, E008 32 '25.8" \\
\hline A40 & F-Block Classes & N $11^{0} 599^{\prime} 24.2^{\prime \prime}$, E008 32 '27.3" \\
\hline A41 & G-Block Classes & N 11 ${ }^{0} 599^{\prime} 25.5^{\prime \prime}$, E00832'25.3" \\
\hline A42 & Shehu Abdulwahab Library & N $11^{0} 599^{\prime} 36.4^{\prime \prime}$, E008 32 '25.5" \\
\hline A43 & MSSN Mosque & N $11^{0} 5927.4^{\prime \prime}$, E008 32 '29.4" \\
\hline A44 & Football Field & N $11^{0} 5928.3^{\prime \prime}$, E008 32 '25.1" \\
\hline $\mathbf{A 4 5}$ & Botanical Garden & N $11^{0} 599^{\prime} 30.8^{\prime \prime}$, E00832'24.5" \\
\hline A46 & Zoological Garden & N $11^{0} 599^{\prime} 32.9^{\prime \prime}$, E008 32 '24.6" \\
\hline A47 & Staff Parking Surface & N $11^{0} 5927.8^{\prime \prime}$, E008 32 '29.3" \\
\hline A48 & Students Parking Surface & N $11^{0} 59^{\prime} 24.7^{\prime \prime}$, E008 32 '28.6" \\
\hline A49 & SOT Ring Road & $\mathrm{N} 11^{0} 5930.0^{\prime \prime}, \mathrm{E} 008^{0} 32$ '28.8" \\
\hline
\end{tabular}

Table 2 presented the results obtained from the measurement of ambient radiation levels at the different laboratories and workshops of the SOT. The mean annual equivalent rate for indoors varies from $1.219 \pm 0.21 \mathrm{mSv} / \mathrm{yr}$ at A1 (New Biology lab) to $2.368 \pm 0.35 \mathrm{mSv} / \mathrm{yr}$ at A11 (Compounding lab) with an average value of $1.726 \pm 0.35 \mathrm{mSv} / \mathrm{yr}$ as presented in the table. From the results A11 (Compounding Lab) and A4 (Old Chemistry Lab) have the highest value of annual equivalent dose rate of $2.368 \pm 0.35 \mathrm{mSv} / \mathrm{yr}$ and $2.169 \pm 0.35 \mathrm{mSv} / \mathrm{yr}$ respectively for all indoor. The higher values obtained are possible due to the following reasons; the rocks used for the foundation of the building were mostly igneous rocks which are believed to be rich in minerals like Zircon, Monazite, Uranite, Potassium, Feldspars and Biotite (Solomon et al, 2002; Wentz, 1998), higher activity levels in the radio-nuclides in the building materials (e.g Soils, blocks and tiles) used in the construction of the laboratories (UNSCEAR, 1998), and the presence of radon gas in air within the laboratory (Felix et al, 2015). The high values obtained in the computer Labs might be due to the radio-nuclide that are present in the building materials and ionizing radiation emitted by the computers, because some of them are operating at the time we took the readings. The annual equivalent dose rate of $1.990 \pm 0.35 \mathrm{mSv} / \mathrm{yr}$ obtained at the Instrumentation lab could be due to the same reasons 
as that of computer labs. A1 (New Biology lab) and A23 (Press Workshop) has the lowest values of $1.219 \pm 0.21 \mathrm{mSv} / \mathrm{yr}$ and $1.303 \pm 0.35 \mathrm{mSv} / \mathrm{yr}$ respectively, the low values might be due to the less amount of radio-nuclide as they contain less tiles compared with other areas. The outdoor annual equivalent dose shown in the table 2 varies from $0.332 \pm 0.07 \mathrm{mSv} / \mathrm{yr}$ to $0.497 \pm 0.12 \mathrm{mSv} / \mathrm{yr}$ with an average value of $0.419 \pm 0.08 \mathrm{mSv} / \mathrm{yr}$. It also shows that
A11 (Compounding Lab) has the highest value of equivalent dose rate of $0.497 \pm 0.12 \mathrm{mSv} / \mathrm{yr}$, while A18 (Power plant lab) has the lowest value of $0.332 \pm 0.07$ $\mathrm{mSv} / \mathrm{yr}$. The average outdoor equivalent dose $0.419 \pm 0.08 \mathrm{mSv} / \mathrm{yr}$ is low compared with $2.4 \mathrm{mSv} / \mathrm{yr}$ limit set by (ICRP, 1990) for worldwide average dose rate for human beings. Table 3 displayed the results obtained from the measurement of the radiation levels in the Studios and lecture venues of the study area.

Table 2: Indoor and Outdoor Ambient Radiation in $(\mu \mathrm{Sv} / \mathrm{hr})$ and $(\mathrm{mSv} / \mathrm{yr})$ for Laboratories and Workshops

\begin{tabular}{|c|c|c|c|c|c|}
\hline $\begin{array}{l}\text { Area } \\
\text { Code }\end{array}$ & $\begin{array}{l}\text { Mean } \\
\mathbf{Y}(\mu \mathrm{Sv} / \mathrm{hr})\end{array}$ & $\begin{array}{l}\text { Mean } \\
\mathrm{Z}(\mu \mathrm{Sv} / \mathrm{hr})\end{array}$ & $\begin{array}{l}\text { IAEDR } \\
(\mathrm{mSv} / \mathrm{yr})\end{array}$ & $\begin{array}{l}\text { OAEDR } \\
(\mathrm{mSv} / \mathrm{yr})\end{array}$ & $\begin{array}{l}\mathbf{R} \\
=\mathrm{Y} / \mathrm{Z}\end{array}$ \\
\hline A1 & $0.174 \pm 0.03$ & $0.218 \pm 0.03$ & $1.219 \pm 0.21$ & $0.381 \pm 0.05$ & 0.79 \\
\hline $\mathbf{A} 2$ & $0.228 \pm 0.1$ & $0.236 \pm 0.06$ & $1.597 \pm 0.70$ & $0.413 \pm 0.12$ & 0.96 \\
\hline $\mathbf{A 3}$ & $0.232 \pm 0.07$ & $0.246 \pm 0.06$ & $1.625 \pm 0.49$ & $0.430 \pm 0.10$ & 0.94 \\
\hline A4 & $0.301 \pm 0.05$ & $0.268 \pm 0.04$ & $2.169 \pm 0.35$ & $0.469 \pm 0.07$ & 1.12 \\
\hline A5 & $0.192 \pm 0.04$ & $0.230 \pm 0.03$ & $1.345 \pm 0.33$ & $0.402 \pm 0.06$ & 0.83 \\
\hline A6 & $0.278 \pm 0.09$ & $0.254 \pm 0.07$ & $1.948 \pm 0.63$ & $0.445 \pm 0.12$ & 1.09 \\
\hline A7 & $0.300 \pm 0.04$ & $0.280 \pm 0.05$ & $2.102 \pm 0.31$ & $0.434 \pm 0.09$ & 1.07 \\
\hline A8 & $0.292 \pm 0.06$ & $0.218 \pm 0.06$ & $2.046 \pm 0.43$ & $0.381 \pm 0.11$ & 1.33 \\
\hline A9 & $0.228 \pm 0.03$ & $0.248 \pm 0.05$ & $1.597 \pm 0.24$ & $0.434 \pm 0.10$ & 0.91 \\
\hline A10 & $0.224 \pm 0.06$ & $0.254 \pm 0.02$ & $1.569 \pm 0.43$ & $0.445 \pm 0.04$ & 0.88 \\
\hline A11 & $0.338 \pm 0.05$ & $0.284 \pm 0.07$ & $2.368 \pm 0.35$ & $0.497 \pm 0.12$ & 1.19 \\
\hline A12 & $0.284 \pm 0.05$ & $0.268 \pm 0.04$ & $1.990 \pm 0.35$ & $0.469 \pm 0.07$ & 1.05 \\
\hline A13 & $0.248 \pm 0.05$ & $0.224 \pm 0.06$ & $1.737 \pm 0.35$ & $0.392 \pm 0.10$ & 1.10 \\
\hline A14 & $0.232 \pm 0.06$ & $0.264 \pm 0.06$ & $1.625 \pm 0.42$ & $0.462 \pm 0.11$ & 0.87 \\
\hline A15 & $0.198 \pm 0.05$ & $0.254 \pm 0.06$ & $1.387 \pm 0.35$ & $0.445 \pm 0.11$ & 0.77 \\
\hline A16 & $0.244 \pm 0.04$ & $0.224 \pm 0.06$ & $1.709 \pm 0.28$ & $0.392 \pm 0.11$ & 1.08 \\
\hline A17 & $0.250 \pm 0.06$ & $0.212 \pm 0.07$ & $1.753 \pm 0.42$ & $0.371 \pm 0.12$ & 1.17 \\
\hline A18 & $0.248 \pm 0.06$ & $0.190 \pm 0.04$ & $1.737 \pm 0.42$ & $0.332 \pm 0.07$ & 1.30 \\
\hline A19 & $0.264 \pm 0.06$ & $0.210 \pm 0.07$ & $1.850 \pm 0.42$ & $0.367 \pm 0.12$ & 1.25 \\
\hline A20 & $0.240 \pm 0.02$ & $0.264 \pm 0.07$ & $1.680 \pm 0.14$ & $0.462 \pm 0.12$ & 0.90 \\
\hline A21 & $0.278 \pm 0.01$ & $0.270 \pm 0.05$ & $1.948 \pm 0.07$ & $0.473 \pm 0.08$ & 1.02 \\
\hline $\mathbf{A 2 2}$ & $0.236 \pm 0.03$ & $0.228 \pm 0.04$ & $1.653 \pm 0.21$ & $0.399 \pm 0.07$ & 1.03 \\
\hline A23 & $0.186 \pm 0.05$ & $0.210 \pm 0.04$ & $1.303 \pm 0.35$ & $0.367 \pm 0.07$ & 0.88 \\
\hline A24 & $0.212 \pm 0.05$ & $0.236 \pm 0.03$ & $1.485 \pm 0.35$ & $0.413 \pm 0.05$ & 0.89 \\
\hline Mean & $0.246 \pm 0.05$ & $0.241 \pm 0.05$ & $1.726 \pm 0.35$ & $0.419 \pm 0.08$ & 1.02 \\
\hline
\end{tabular}

Table 3: Indoor and Outdoor Ambient Radiation in $(\mu \mathrm{Sv} / \mathrm{hr})$ and $(\mathrm{mSv} / \mathrm{yr})$ for Studios and Lecture Venues

\begin{tabular}{llllll}
$\begin{array}{l}\text { Area } \\
\text { Code }\end{array}$ & $\begin{array}{l}\mathbf{M e a n} \\
\mathbf{Y}(\boldsymbol{\mu S v} / \mathbf{h r})\end{array}$ & $\begin{array}{l}\mathbf{M e a n} \\
\mathbf{Z}(\boldsymbol{\mu S v} / \mathbf{h r})\end{array}$ & $\begin{array}{l}\mathbf{I A E D R} \\
(\mathbf{m S v} / \mathbf{y r})\end{array}$ & $\begin{array}{l}\text { OAEDR } \\
(\mathbf{m S v} / \mathbf{y r})\end{array}$ & $\begin{array}{l}\mathbf{R} \\
\mathbf{=} / \mathbf{Z}\end{array}$ \\
\hline A25 & $0.184 \pm 0.06$ & $0.276 \pm 0.08$ & $1.288 \pm 0.42$ & $0.483 \pm 0.14$ & 0.66 \\
A26 & $0.222 \pm 0.04$ & $0.286 \pm 0.10$ & $1.555 \pm 0.28$ & $0.501 \pm 0.18$ & 0.77 \\
A27 & $0.200 \pm 0.04$ & $0.186 \pm 0.03$ & $1.401 \pm 0.28$ & $0.325 \pm 0.05$ & 1.07 \\
A28 & $0.252 \pm 0.02$ & $0.234 \pm 0.05$ & $1.766 \pm 0.14$ & $0.409 \pm 0.08$ & 1.07 \\
A29 & $0.248 \pm 0.04$ & $0.218 \pm 0.05$ & $1.737 \pm 0.29$ & $0.381 \pm 0.05$ & 1.13 \\
A30 & $0.208 \pm 0.06$ & $0.242 \pm 0.04$ & $1.457 \pm 0.42$ & $0.423 \pm 0.08$ & 0.85 \\
A31 & $0.294 \pm 0.07$ & $0.264 \pm 0.08$ & $2.060 \pm 0.49$ & $0.462 \pm 0.14$ & 1.11 \\
A32 & $0.206 \pm 0.02$ & $0.186 \pm 0.04$ & $1.443 \pm 0.10$ & $0.325 \pm 0.07$ & 1.10 \\
A33 & $0.182 \pm 0.03$ & $0.222 \pm 0.01$ & $1.275 \pm 0.27$ & $0.388 \pm 0.02$ & 0.81 \\
A34 & $0.226 \pm 0.05$ & $0.232 \pm 0.05$ & $1.583 \pm 0.39$ & $0.406 \pm 0.09$ & 0.97 \\
A35 & $0.212 \pm 0.05$ & $0.206 \pm 0.06$ & $1.485 \pm 0.36$ & $0.360 \pm 0.11$ & 1.02 \\
A36 & $0.184 \pm 0.04$ & $0.260 \pm 0.04$ & $1.289 \pm 0.32$ & $0.455 \pm 0.07$ & 0.70 \\
A37 & $0.274 \pm 0.04$ & $0.246 \pm 0.06$ & $1.920 \pm 0.28$ & $0.430 \pm 0.11$ & 1.11 \\
A38 & $0.262 \pm 0.03$ & $0.242 \pm 0.07$ & $1.836 \pm 0.21$ & $0.423 \pm 0.12$ & 1.08 \\
A39 & $0.244 \pm 0.04$ & $0.230 \pm 0.05$ & $1.709 \pm 0.28$ & $0.402 \pm 0.08$ & 1.06 \\
A40 & $0.204 \pm 0.03$ & $0.202 \pm 0.05$ & $1.429 \pm 0.21$ & $0.353 \pm 0.08$ & 1.00 \\
A41 & $0.242 \pm 0.06$ & $0.194 \pm 0.05$ & $1.695 \pm 0.42$ & $0.339 \pm 0.08$ & 1.24 \\
A42 & $0.198 \pm 0.03$ & $0.240 \pm 0.03$ & $1.380 \pm 0.22$ & $0.420 \pm 0.06$ & 0.82 \\
A43 & $0.216 \pm 0.03$ & $0.258 \pm 0.03$ & $1.513 \pm 0.21$ & $0.452 \pm 0.05$ & 0.83 \\
Mean & $0.224 \pm 0.04$ & $0.232 \pm 0.05$ & $1.427 \pm 0.29$ & $0.446 \pm 0.08$ & 0.96 \\
\hline & & & & &
\end{tabular}

The indoor annual equivalent dose rate varies from $1.275 \pm 0.27 \mathrm{mSv} / \mathrm{yr}$ to $2.060 \pm 0.49 \mathrm{mSv} / \mathrm{yr}$ with an average value of $1.427 \pm 0.29 \mathrm{mSv} / \mathrm{yr}$. The results show that A31 (Auditorium) and A37 (ND Mechanical Engineering Class) has the highest indoor annual equivalent dose rate of $2.060 \pm 0.49 \mathrm{mSv} / \mathrm{yr}$ and $1.920 \pm 0.28 \mathrm{mSv} / \mathrm{yr}$ respectively, while A33 (H-block
ND I Textile class) and A25 (Prof. Hafiz Abubakar Studio Hall II) recorded the lowest values of $1.275 \pm 0.27 \mathrm{mSv} / \mathrm{yr}$ and $1.288 \pm 0.42 \mathrm{mSv} / \mathrm{yr}$ respectively. High levels of indoor radiation recorded at Auditorium and ND Mechanical Engineering class might be attributed to the rocks used for the construction of the buildings were mostly igneous 
rocks which are believed to be rich in minerals like zircon, monazite, uranite, potassium, feldspars and biotite (Ogola et al., 2016) which release ionizing radiation, higher activity levels in the radio-nuclides in the building materials (e.g Soils, blocks and tiles) used in the construction of the laboratories (UNSCEAR, 1998), and the presence of radon gas in air within the laboratory (Felix et al, 2015). Furthermore, elevated radiation levels may be due to the way some of the buildings were constructed as part of the roof is made up of concrete (Ogola et al., 2016). The Altitude of the area might also be the contributing factor to the radiation levels (Sadiq and Agba, 2012). The high level of radiation obtained at A38 (HND Mechanical Engineering class) could be due to the same reasons as that ND Mechanical Engineering class because they are very close to each other. The low levels of radiation obtained at A33 (H-Block NDI Textile class) and A25 (Prof. Hafiz Abubakar Studio Hall I) might be due to low activity from the foundation rocks used in the buildings and the classes in the areas are not closely built together, therefore there is proper ventilation of air which leads to low accumulation of radon gas inside the respective venues. The outdoor annual equivalent dose rate recorded ranges from $0.325 \pm 0.07$ $\mathrm{mSv} / \mathrm{yr}$ to $0.501 \pm 0.18 \mathrm{mSv} / \mathrm{yr}$ with an overall average of $0.446 \pm 0.08 \mathrm{mSv} / \mathrm{yr}$. A26 (Prof. Hafizu Abubakar Studio Hall II) has the highest value while A32 (HBlock ND II Fashion Class) has the lowest value as can be seen from the table. All the values obtained from these areas were low compare to 2.4 limit set by the ICRP (1990) for human being protection against ionizing radiation.

Table 4: Ambient Radiation in $(\mu \mathrm{Sv} / \mathrm{hr})$ and $(\mathrm{mSv} / \mathrm{yr})$ for Outdoor Areas

\begin{tabular}{llll}
\hline Area code & Location & Mean $(\boldsymbol{\mu S v} / \mathbf{h r})$ & OAEDR(mSv/yr) \\
\hline $\mathbf{A 4 4}$ & Football Field & $0.216 \pm 0.08$ & $0.378 \pm 0.15$ \\
$\mathbf{A 4 5}$ & Botanical Garden & $0.212 \pm 0.03$ & $0.371 \pm 0.05$ \\
$\mathbf{A 4 6}$ & Zoological Garden & $0.160 \pm 0.03$ & $0.280 \pm 0.05$ \\
$\mathbf{A 4 7}$ & Staff Parking Surface & $0.200 \pm 0.02$ & $0.350 \pm 0.03$ \\
$\mathbf{A 4 8}$ & Students Parking Surface & $0.256 \pm 0.07$ & $0.448 \pm 0.12$ \\
$\mathbf{A 4 9}$ & SOT Ring Road & $0.318 \pm 0.10$ & $0.557 \pm 0.17$ \\
& Mean & $0.227 \pm 0.05$ & $0.397 \pm 0.09$ \\
\hline
\end{tabular}

Table 4 presents the results obtained from the outdoor areas, the annual equivalent dose rate varies from $0.280 \pm 0.05 \mathrm{mSv} / \mathrm{yr}$ to $0.557 \pm 0.17 \mathrm{mSv} / \mathrm{yr}$ with an overall average of $0.397 \pm 0.09 \mathrm{mSv} / \mathrm{yr}$. The highest value was obtained along A49 (SOT ring road) while the lowest value was recorded at A46 (Zoological Garden). These values were also below $2.4 \mathrm{mSv} / \mathrm{yr}$ recommended by International Commission for Radiological Protection (ICRP, 1990). The Indoor-toOutdoor ratio was also computed for comparison with 1.5 set by UNSCEAR (UNSCEAR, 1993).

Conclusion: The assessment of Indoor and Outdoor background radiation of School of Technology, Kano State Polytechnic was carried out using Digital Radiation Meter. The measurements were carried out in 49 different areas within the school. The results obtained shows that the Staff and Students are exposed to an insignificant health risk of ionizing radiation since the values of the mean indoor and outdoor annual equivalent dose rate recorded are less than the world wide sets limit. Hence regular and periodic monitoring of the background ionising radiation level should be carried out to assess the health risk of inhabitants.

Acknowledgement: We wish to express our profound gratitude to the Department of Physics Federal University Dutsin-Ma, Katsina state Nigeria for providing us with equipment used for this work, and our sincere appreciation goes to the management of School of Technology, Kano State Polytechnic for their kind assistance and support in one way or the other in the course of this research study.

\section{REFERENCES}

Chad-Umoren, YE; Adekanmbi, M; Harry, SO (2007). Evaluation of Indoor Background Ionizing Radiation Profile of a Physics Laboratory. Facta. Univ. Series: Work. Liv. Environ. Protec. 3(1): 17.

Farai, IP; Vincent, UE (2006). Outdoor Radiation Level Measurement in Abeokuta, Nigeria. Nig. $J$. Phy. 18(1): 121-126.

Felix, BM; Robert, RD; Emmanuel, WM (2015). Assessment of Indoor and Outdoor Background Radiation Levels in Plateau State University Bokkos, Jos, Nigeria. J. Environ. Ear. Sci. 5(8).

Ghiassi-nejad, M; Mortazavi, SMJ; Cameron, JR; Niroomand-rad, A; Karam, PA (2002). Very high background radiation areas of Ramsar, Iran: Preliminary Biological studies. H. Phys.82: 8793.

Gholami, M; Mirzael, S; Jomehzadeh, A (2011). Gamma background radiation measurement in Lorestan Province, Iran. Iran. J. Radiat. Res. 9: 89-93.

ICRP (1990). Age Dependence Dose to the Member of Public from Intake of Radionuclides. Part 1. Int. Comm. Rad. Prot. (ICRP) Publ. 56. London: Perga. Press, Oxford.

James, IU; Moses, IF; Vandi, JN; Ikoh, UE (2015). Measurement of Indoor and Outdoor Background 
Ionising Radiation Levels of Kwali General Hospital, Abuja. J. Appl. Sci. Environ. Manage. 19 (1) $89-93$.

Masok, FB; Dawan, RR; Mangset, WE (2015). Assessment of Indoor and Outdoor Background Radiation Levels in Plateau State University, Bokkos, Jos, Nigeria. IISTE. J. Environ. Ear. Sci. 5(8): 1-4.

Ogola, PE; Arika, WM; Nyamai, DW; Osano KO; Rachuonyo, HO (2016). Determination of Background Ionizing Radiations in Selected Buildings in Nairobi County, Kenya. J Nucl. Med. Radiat. Ther. 7: 289.

Post Offices- with map of LGA. NIPOST. Archived from the original on 2009-10-07. Retrieved 200910-20.

Prenhall.com (2015). Detection of Radiation. Wps.prenhall.com/wps/media/objects/ 3084/3158429/blb2015.html. Retrieved on $6 / 01 / 2019$ at 20.00GMT

Sadiq, AA; Agba, EH (2012). Indoor and Outdoor Ambient Radiation Levels in Keffi, Nigeria. $S$. Work. Liv. Environ. Protec. 9(1): $19-26$.
Solomon, AO; Ike, EE; Ashano, EC; Jwanbot, DI (2000). Natural Background Radiation Characteristics of Basalt on the Jos Plateau and Radiological Implication of the Use of Rock for House Construction. Afri. J. Nat. Sci.5.

Tikyaa, EV; Atsue, T; Adegboyega, J (2017). Assessment of the Ambient Background Radiation Levels at the Take-Off Campus of Federal University Dutsin-Ma, Katsina StateNigeria. FUDMA. J. Sci. (FJS) Maid. Edit. 1(1): 58-68.

UNCSEAR (1988). Report to the General Assembly Scientific Annexes. New York; United Nations.

UNSCEAR (2000). Sources and Effect of Ionizing Radiation. United Nation Scientific Committee on the Effects of Atomic Radiation Report to the General Assembly with Scientific Annexes. New York: United Nations.

Wentz, CA (1998). Safety, Health and Environmental Protection. Mc Gram. H. Bost. USA: 206-219. 